\title{
17 Enzyme Immobilization in Biodegradable Polymers for Biomedical Applications
}

\author{
S. A. Costa, Helena S. Azevedo, and Rui L. Reis
}

\section{CONTENTS}

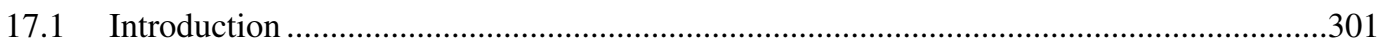

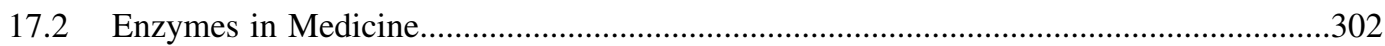

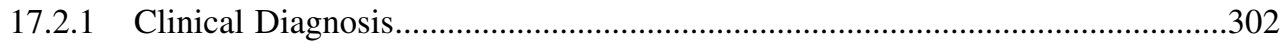

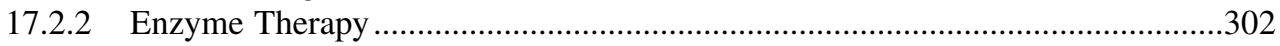

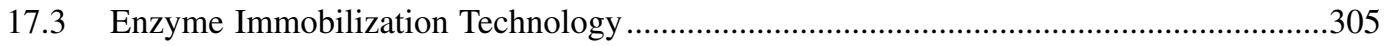

17.3.1 Methods for Immobilizing Enzymes in Polymeric Carriers ..............................305

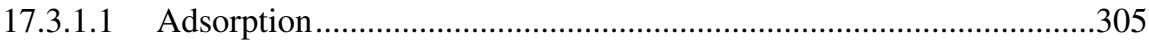

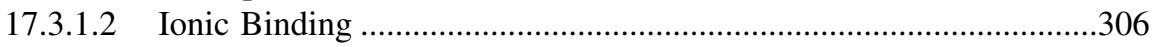

17.3.1.3 Covalent Binding by Chemical Coupling .........................................307

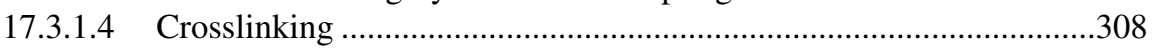

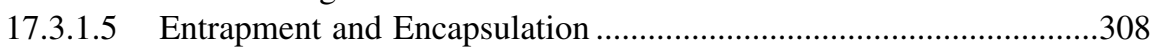

17.3.1.6 Protein Fusion to Affinity Ligands and Enzymatic Conjugation.......309

17.3.2 Enzyme Immobilization in Biomedical Applications ...........................................311

17.3.2.1 Biologically Functional Surfaces.........................................................311

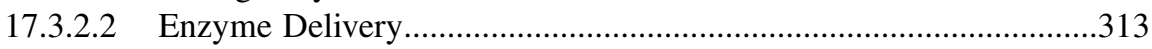

17.3.2.3 Bioreactors for Extracorporeal Enzyme Therapy................................315

17.3.2.4 Diagnostic Assays and Biosensors ....................................................316

17.3.2.5 Advantages and Disadvantages of Immobilized Enzymes .................317

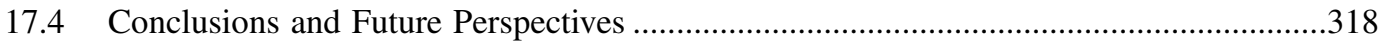

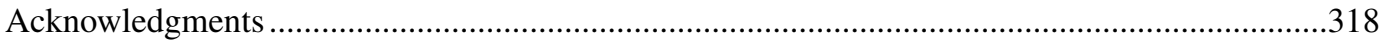

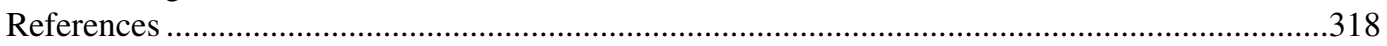

\subsection{INTRODUCTION}

During the last three decades, enzymology and enzyme technology have progressed considerably and, as a result, there are many examples of industrial applications where enzymes, in the native or immobilized form, are being used. These include food industry, materials processing, textiles, detergents, biochemical and chemical industries, biotechnology, and pharmaceutical uses. ${ }^{1}$ The overall impact of enzymes on industrial applications is, however, still quite limited due to their relative instability under operational conditions, which may involve high temperatures, organic solvents, and exposure to other denaturants. Various approaches, including, among others, addition of additives, ${ }^{2,3}$ chemical modification, ${ }^{4,5}$ protein engineering, ${ }^{6}$ and enzyme immobilization, ${ }^{1,7}$ have been assessed for their ability to increase the stability of enzymes toward heat or denaturants. ${ }^{7,8}$ 
The use of enzymes in medical applications has been less extensive as those for other types of industrial applications. For example, pancreatic enzymes have been in use since the nineteenth century for the treatment of digestive disorders. At present, the most successful applications of enzymes in medicine are extracellular, such as topical uses, removal of toxic substances, and the treatment of life-threatening disorders within the blood circulation. ${ }^{9}$ The production of therapeutic enzymes has progressed, but the costs of enzyme production, isolation, and purification are still too high to make them available for clinical applications. Furthermore, the ability to store unstable enzymes for long periods of time is also a limitation for their more widespread use. Most applications in the biomedical field are still in the state of basic studies rather than definite applications, owing to the absence of the necessary information on toxicology, hemolysis, allergenicity, immunological reactions, and chemical stability of the system in vivo. ${ }^{9,10}$

This chapter will focus on the importance of using enzymes in medical applications and, in particular, the use of immobilized enzymes. For that, some aspects of enzyme immobilization technology, including the traditional physical and chemical methods and new immobilization methodologies, based on biological and genetic engineering approaches, will be reviewed. Several examples will be given of immobilized enzymes in various support materials and using different immobilization strategies, according to the objective of their application in the biomedical field.

\subsection{ENZYMES IN MEDICINE}

Since the mid-1950s there has been a considerable increase in both measurement of enzyme activities and the use of purified enzymes in clinical practice. In recent years, many enzymes have been isolated and purified, and this made it possible to use enzymes to determine the concentration of substrates and products of clinical importance. A further development, arising from the increased availability of purified enzymes, has been targeted to enzyme therapy.

\subsubsection{Clinical Diagnosis}

The measurement of enzyme activities in serum is of major importance as an aid in diagnosis, being used as means of monitoring progress after therapy, recovery after surgery, and detection of transplant rejection. Urine can be also analyzed for determination of enzyme activities since the detection of certain enzymes in urine may indicate kidney damage or failure. ${ }^{11}$ On the other hand, the concentration of certain metabolites in serum or urine may be determined by enzymatic methods. The method consists of using an enzyme to transform a metabolite into its product and then estimate the amount of transformed substrate. The use of enzymatic methods presents several advantages, such as the high specificity of the enzyme to estimate the concentration of the metabolite in the presence of other substances, avoiding the need of purification steps prior to chemical analysis. In addition, enzymatic reactions are performed at mild conditions, allowing the analysis of labile compounds that would be degraded by harsher chemical methods. The cost of purified enzymes may be, however, too high to support routine analysis, but the use of immobilized enzymes allows for enzyme reuse and the application of immobilized enzymes for diagnostic assays and as biosensors will be further discussed in Section 17.3.2.4 of this chapter. The determination of serum metabolites in serum by enzymatic methods includes a wide range of substances such as glucose, uric acid, urea, cholesterol, cholesterol esters, triglycerides, and creatine, among others. ${ }^{11}$

\subsubsection{EnZyme Therapy}

Many inborn metabolic disorders are associated with the absence of activity of one particular enzyme normally found in the body. Of the 1250 autosomal recessive human genetic diseases, over 200 involve errors in metabolism that result from specific known enzyme deficiencies. ${ }^{12}$ Table 17.1 lists some examples of inborn errors or disorders in metabolism due to enzyme deficiencies. 


\section{TABLE 17.1 \\ Some Examples of Inborn Errors and Disorders Associated with Enzyme Deficiencies}

Inborn Error/Disorder

Gaucher disease
Acatalasemia
Hypophosphatasia
Glycogen storage disease type Ia
Alkaptonuria
Phenylketonuria
Fructosuria
Pentosuria
Tay-Sachs
Infantile neuronal ceroid
lipofuscinosis (INCL)
Cystic fibrosis
Albinism
Glucose-6-phosphate dehydrogenase
deficiency
Neonatal jaundice
Prolidase deficiency (PD)
Pompe's disease
Severe combined immunodeficiency
(SCID)
Xanthinuria

\section{Enzyme Deficiency}

Glucocerebrosidase
Catalase
Alkaline phosphatase
Glucose 6-phosphatase
Homogentisate 1,2-dioxygenase
Phenylalanine 4-monooxygenase
Fructokinase
L-Xylulose reductase
$\beta$ - $N$-acetyl-D-hexosaminidase
Palmitoyl protein thioesterase 1
(PPT1)
Cystic fibrosis transmembrane
conductance regulator
Tyrosinase
Glucose-6-phosphate
dehydrogenase
Biotinidase
Prolidase
$\alpha$-glucosidase
Adenosine deaminase
Xanthinine oxidase

$$
\text { Frequency }(\%)
$$

Ref.

$\begin{array}{ll}0.003-0.002 & 11,13-15 \\ 0.004-0.004 & 11 \\ \approx 0.001 & 11,15 \\ 0.001 & 11,15 \\ 0.0001-0.001 & 11 \\ 0.005-0.01 & 11,15,16 \\ 0.0008 & 11 \\ 0.04 \text { in Ashkenazi Jews } & 11 \\ 0.0003 & 11,13-15 \\ \approx 0.013 \text { live births } & 17,18 \\ & \\ 0.03-0.05 \text { Caucasians, rare } & 11 \\ \text { in other ethnic groups } & \\ 0.02 \text { schoolchildren in } & 16,19,20 \\ \text { Zimbabwe } & 11,21,22 \\ 0.5-26 & \\ & 23,24 \\ 0.0025 & 25 \\ - & 13,14 \\ - & 12,15,26 \\ - & 12 \\ - & \end{array}$

The initial identification of the disease may be difficult to determine and normally requires a tissue biopsy. For some genetic diseases, DNA probes are now available that can be used on small amounts of blood, cells, or amniotic fluid. Albinism, for example, is often caused by the absence of tyrosinase, an enzyme essential for the production of cellular pigments. Tyrosinase is a coppercontaining enzyme that catalyzes the first two rate-limiting steps in the melanin biosynthetic pathway, the oxidation of tyrosine to dopa and the subsequent dehydrogenation of dopa to dopaquinone. The human tyrosinase gene, encoding 529 amino acids, consists of five exons spanning more than $50 \mathrm{~Kb}$ of DNA in chromosomes. ${ }^{20}$ When homozygous mutations of the tyrosine gene result in complete absence of melanogenic activity, such a patient, categorized as tyrosinasenegative oculocutaneous albinism, will never develop any melanin pigment in the skin, hair, and eyes throughout his or her life. ${ }^{20}$ Some inborn errors in metabolism are relatively harmless, e.g., albinism or alkaptonuria, but others must be detected early if the defect is to be circumvented. This is the case of phenylketonuria, where the enzyme phenylalanine 4-monooxygenase (enzyme that converts phenylalanine into tyrosine) is missing. Phenylketonuria results in the accumulation of phenylalanine, which may cause mental retardation. Patients with phenylalanine 4-monooxygenase deficiency must follow a phenylalanine-free diet in order to avoid the accumulation of deleterious effects. Phenylalanine is, however, an amino acid essential to maintain growth and protein turnover, and thus it must be supplied in a minimal amount required to maintain normal metabolism. Such a dietary scheme is normally carried out ${ }^{11,16}$ by lowering the amount of protein consumed, but this may cause a deficiency in other essential amino acids. A possible alternative to this therapy is to replace the missing enzyme. It may be difficult to find, however, an enzyme with the same function from a human source since the direct administration of enzymes from other sources into the body would cause an adverse immunological response. A possible approach to circumvent this problem 


\section{TABLE 17.2 \\ Enzymes with Therapeutic Importance for Medical Applications}

\section{Enzyme}

Lysozyme

Urease

Catalase

Glucose-6-phosphate

dehydrogenase

Collagenase

Glucose oxidase

Asparaginase

$\alpha$-amylase, protease,

lipase

Chymotrypsin and pepsin

Trypsin

Streptokinase

Hyaluronidase

Heparinase

Urokinase

Streptodornase

Tissue plasminogen

activator (TPA)

Tyrosinase

Bilirubin oxidase

Penicillinase

Alkaline phosphatase
Typical Applications

Ref.

\begin{tabular}{|c|c|}
\hline $\begin{array}{l}\text { Recommended in treatment of certain ulcers, measles, multiple sclerosis, some } \\
\text { skin diseases, and postoperative infections (antibacterial agent) }\end{array}$ & $27-29$ \\
\hline Biosensor and artificial kidneys & $30-32$ \\
\hline Treatment of acatalasemia and removal of hydrogen peroxide in human cells & $33-35$ \\
\hline Treatment of jaundice & $36-38$ \\
\hline Skin ulcers & 11 \\
\hline Glucose test in blood and urine & 39,40 \\
\hline Anticancer agent (leukemia) & $41-43$ \\
\hline Digestive aids & 44 \\
\hline Catalyzes the hydrolysis of peptide bonds of proteins in the small intestine & 45 \\
\hline Anti-inflammatory agent, wound cleanser & $44,46,47$ \\
\hline Anti-inflammatory agent, dissolution of blood clots in myocardial infarction & 45 \\
\hline $\begin{array}{l}\text { Hydrolyses polyhyaluronic acid, a relatively impermeable polymer found } \\
\text { between human cells; administered to increase diffusion of coinjected } \\
\text { compounds, e.g., antibiotics, adrenaline, heparin, and local anesthetic in } \\
\text { surgery and dentistry. }\end{array}$ & $48-51$ \\
\hline $\begin{array}{l}\text { Removal of heparin after surgery. Production of heparin oligosaccharides } \\
\text { (wound healing and tumor netastasis properties). }\end{array}$ & 52,53 \\
\hline Prevention and removal of blood clots & $54-56$ \\
\hline Anti-inflammatory agent & 57 \\
\hline Dissolution of blood clots & 58 \\
\hline Enzyme essential for the production of cellular pigments & $20,59,60$ \\
\hline Treatment of neonatal jaundice & 61 \\
\hline Removal of allergenic form of penicillin from allergic individuals & 16 \\
\hline Treatment of hypophosphatasia & 15 \\
\hline
\end{tabular}

involves the isolation of the enzyme within a microcapsule, fiber, or gel, which will protect the enzyme from proteolysis and avoid the undesirable immunological response (please see Section 17.3.2.2 of this chapter).

The pharmacological properties of enzymes have been employed to replace enzymes that are missing or defective as a consequence of an inherited disease or malfunction of an organ where they are normally synthesized or to accomplish a certain biological effect that is dependent on the catalytic activity of the enzyme. Therefore, depending on the treatment, the administration of enzymes as therapeutic agents can be subdivided into two categories ${ }^{9,11}$ : (1) the topical application of an enzyme as an extracellular agent and (2) the intracellular applications of enzymes to treat metabolic deficiency and related disease. The main areas where enzyme therapy has been applied are the degradation of necrotic tissue by the use of proteolytic enzymes, removal of toxic compounds from the blood, treatment of genetic deficiency diseases and cancer, and treatment of pancreatic insufficiency. ${ }^{11}$ In Table 17.2 are given some examples of areas where enzyme therapy may be used.

Enzymes may be administered either intra- or extracorporeally, depending on the objective. If the enzyme is to be used for the removal or transformation of a substance present in the blood (e.g., toxic metabolite or a blood clot), then it is only necessary for the enzyme to be present in the blood and not necessary for the enzyme to enter the intracellular compartments. This type of application may be either intra- or extracorporeal using a bypass as in kidney dialysis. These systems 
will be described in more detail in Section 17.3.2.3 of this chapter. For intracellular therapy, it is necessary for the enzyme to be taken up by the appropriate target cells.

Although the attempts made with enzyme therapy in clinical trials have so far had limited success, it is reasonable to assume that the delivery of enzymes (discussed in Section 17.3.2.2 of this chapter) would constitute a feasible approach for the treatment of certain diseases in the near future.

\subsection{ENZYME IMMOBILIZATION TECHNOLOGY}

The term immobilized enzyme was adopted in $1971^{62}$ at the first Enzyme Engineering Conference. It describes enzymes physically confined at or localized in a certain region of space with retention of catalytic activity and which can be used repeatedly and continuously. ${ }^{63}$ The immobilization of biocatalysts (not only enzymes but also other bioactive molecules such as growth factors and hormones, cellular organelles, microbial cells, and plant and animal cells) is attracting worldwide attention in biotechnology applications. In general, immobilized biocatalysts are more stable and easier to handle compared with their free counterparts. ${ }^{64}$ At present, applications of immobilized biocatalysts include the production of useful compounds by stereospecific or regiospecific bioconversion, the production of energy by biological processes, the selective treatment of specific pollutants to solve environmental problems, continuous analyses of compounds with a high sensitivity and specificity, and medical uses such as new types of drugs for enzyme therapy or artificial organs. ${ }^{14}$ Immobilized enzymes are already being used in medical applications for clinical diagnosis and also for intra- and extracorporeal enzyme therapy. ${ }^{62}$ Applications in clinical analysis are mainly related to biosensors, which have been used to detect the presence of various organic compounds for many years. For example, glucose oxidase and catalase have been used to measure blood glucose concentration, and cholesterol oxidase and cholesterol esterase to determine cholesterol levels. ${ }^{31}$ In addition, enzymes can be immobilized on different prosthetic devices or used extracorporeally (e.g., artificial heart, artificial lung, artificial kidney, equipment for hemodialysis and specific blood purification) as surface modifiers in order to increase the biocompatibility of these devices and to prevent blood clotting. ${ }^{9}$

\subsubsection{Methods for Immobilizing Enzymes in Polymeric Carriers}

Various methods have been developed ${ }^{10,65}$ for the immobilization of biocatalysts, which are being used extensively today. A wide range of support materials has also been employed for enzyme immobilization. The support type can be classified according to their chemical composition, such as organic or inorganic supports, and the former can be further classified into natural or synthetic matrices. ${ }^{66}$ Immobilization techniques can be divided into different categories: physical, ${ }^{67}$ chemical, ${ }^{68}$ enzymatic, ${ }^{69}$ and genetic engineering methods. ${ }^{53}$

\subsubsection{Adsorption}

The adsorption of an enzyme onto a support or film material is the simplest method of obtaining an immobilized enzyme. Basically, the enzyme is attached to the support material by noncovalent linkages and does not require any preactivation step of the support. The interactions formed between the enzyme and the support material will be dependent on the existing surface chemistry of the support and on the type of amino acids exposed at the surface of the enzyme molecule. Enzyme immobilization by adsorption involves, normally, weak interactions between the support and the enzyme such as ionic or hydrophobic interactions, hydrogen bonding, and van der Waals forces (see Figure 17.1). ${ }^{70,71}$

Most of the support materials available have sufficient surface-charge properties suitable for immobilization by adsorption. They include inorganic carriers ${ }^{62}$ (ceramic, alumina, activated carbon, kaolinite, bentonite, porous glass), organic synthetic carriers ${ }^{72}$ (nylon, polystyrene), and natural 


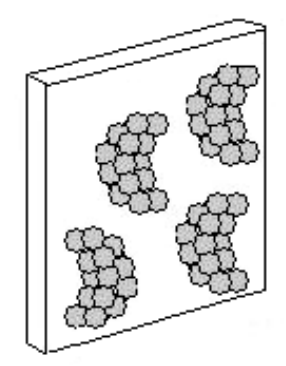

FIGURE 17.1 Biocatalysts bound to a carrier by adsorption.

organic carriers ${ }^{1}$ (chitosan, dextran, gelatin, cellulose, starch). The method consists of simply mixing an aqueous solution of enzyme with the support material for a period of time, after which the excess enzyme is washed away from the immobilized enzyme on the support. The procedure requires strict control of the $\mathrm{pH}$ and ionic strength, because these can alter the charges of the enzyme and the support and therefore affect the level of adsorption. A simple shift in pH can cancel ionic interactions and promote the release of the enzyme from the support. The main advantages of adsorption are the method simplicity, the little effect on the conformation/activity of the biocatalyst, and the possibility of regenerating inactive enzyme by addition of fresh enzyme. The main disadvantage is the desorption of the biocatalyst from the support due to the weak interactions established. The enzyme desorption can easily occur by changes in the environment medium such as $\mathrm{pH}$, temperature, solvent, and ionic strength or in the case of extended reactions. ${ }^{73}$

\subsubsection{2 lonic Binding}

Immobilization via ionic binding is based, mainly, on ionic binding of enzyme molecules or active molecule to solid supports containing ionic charges. In this method, the amount of enzyme bound to the carrier and the activity after immobilization depends on the nature of the carrier. Figure 17.2 shows how the enzyme is bound to the carrier. In some cases, physical adsorption may also take place. The main difference between ionic binding and physical adsorption is the strength of the interaction, which is much stronger for ionic binding, although less strong than covalent binding. The preparation of immobilized enzymes using ionic binding is based on the same procedure as described for physical adsorption. ${ }^{74,75}$ The ionic nature of the binding forces between the enzyme and the support also depends on $\mathrm{pH}$ variations, support charge, enzyme concentrations, and temperature. The supports used for ionic binding may be based on polysaccharide derivatives ${ }^{64}$ (e.g., diethylaminoethylcellulose, dextran, chitosan, carboxymethylcellulose), synthetic polymers ${ }^{10}$ (e.g.,

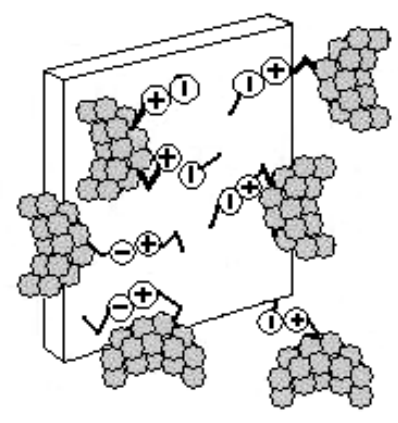

FIGURE 17.2 Biocatalysts bound to a carrier by ionic binding. 
polystyrene derivatives, polyethylene vinylalcohol), and inorganic materials ${ }^{62}$ (e.g., ambertite, alumina, silicates, bentonite, sepiolite, silica gel, etc.). The immobilization by ionic binding has the advantage that changes in the enzyme conformation only occur in a small extent, resulting in immobilized enzymes with high enzymatic activities. The main disadvantage is the possible interference of other ions, and special attention should be paid in maintaining the correct ionic strength and $\mathrm{pH}$ conditions in order to prevent their easy detachment. ${ }^{10}$

\subsubsection{Covalent Binding by Chemical Coupling}

The covalent binding method is based on the binding of enzymes, or other active molecules, to a support or matrix by means of covalent bonds. ${ }^{10}$ The bond is normally formed between a functional group present on the support surface and amino acid residues on the surface of the enzyme. Those which are most often involved in covalent binding are ${ }^{65}$ the amino $\left(\mathrm{NH}_{2}\right)$ group of lysine or arginine, carboxyl $\left(\mathrm{CO}_{2} \mathrm{H}\right)$ group of aspartic acid or glutamic acid, hydroxyl $(\mathrm{OH})$ group of serine or threonine, and sulphydryl (SH) group of cysteine. ${ }^{76,77}$ There are many reaction procedures for joining an enzyme to a material with a covalent bond (diazotation, amino bond, Schiff's base formation, amidation reactions, thiol-disulfide, peptide bond, and alkylation reactions). The connection between the support and the biocatalyst can be achieved either by direct linkage between the components or via an intercalated link of different length, the so-called spacer or harm. The advantage of using a spacer molecule is that it gives a greater degree of mobility to the coupled biocatalysts so that its activity can, under certain circumstances, be higher than if it is bound directly to the support (see Figure 17.3). It is important to choose a method that will not involve the reaction with the amino acids present in the active site, since this could inactivate the enzyme. Basically, two steps are involved in the covalent binding of enzymes to a support material. First, functional groups on the support material are activated by specific reagents (e.g., cyanogen bromide, carbodiimide, aminoalkylethoxysilane, isothiocyanate, and epichlorohydrin, etc.). A large range of support materials is available for covalent binding, and this extensive range reflects the fact that no ideal matrix exists. Therefore, the advantages and disadvantages of a given matrix must be taken into account when considering the appropriate procedure for a given enzyme immobilization. Immobilization of enzymes through covalent attachment has also been demonstrated ${ }^{73}$ to induce higher resistance to temperature, denaturants, and organic solvents in several cases. The extent of these improvements may depend on other conditions of the system, e.g., the nature of the enzyme, type of support, and the method of immobilization. Many factors may influence the selection of the support, and some of the more important are its cost and availability, the binding capacity (amount of enzyme bound per given weight of matrix), hydrophilicity (the ability to incorporate water into the matrix and stability of matrix), structural rigidity, and durability during applications. Natural polymers, which are very hydrophilic, are popular support materials for enzyme immobilization since the residues in these

(a)

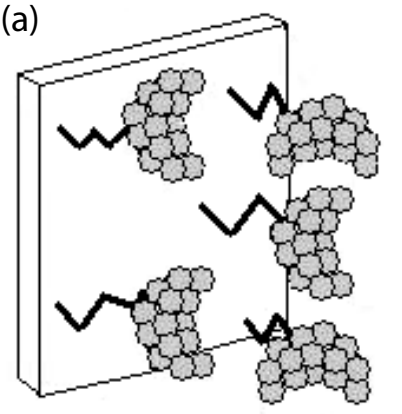

(b)

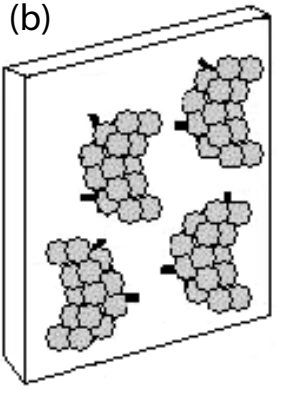

FIGURE 17.3 Covalent bond between the biocatalysts and a carrier with (a) and without spacer (b). 
(a)

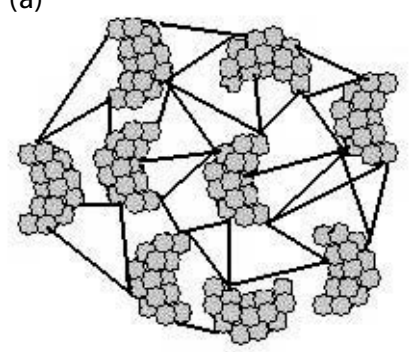

(b)

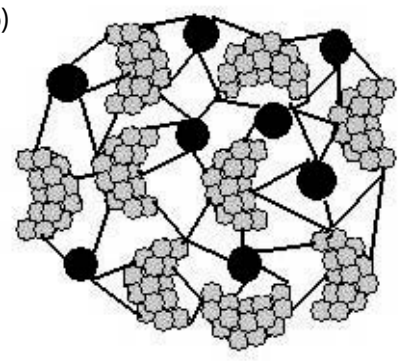

FIGURE 17.4 Biocatalysts immobilized by means of crosslinking (a) and co-crosslinking with inert molecules incorporated (b).

polymers contain hydroxyl groups, which are ideal functional groups for participating in covalent bonds. A frequently encountered disadvantage of immobilization by covalent binding is that it places great stress on the enzyme. The necessary harshness of the immobilization procedure nearly always leads to considerable changes in conformation and a resultant loss of catalytic activity. ${ }^{72,78,79}$

\subsubsection{Crosslinking}

The crosslinking method is based on the formation of covalent bonds between the enzyme or active molecules, by means of bi- or multifunctional reagents. ${ }^{80,81}$ The individual biocatalytic units (enzymes, organelles, whole cells) are joined to one another with the help of bi- or multifunctional reagents (e.g., glutardialdehyde, glutaraldehyde, glyoxal, diisocyanates, hexamethylene diisocyanate, toluene diisocyanate, etc.). Enzyme crosslinking involves normally the amino groups of the lysine but, in occasional cases, the sulfhydryl groups of cysteine, phenolic OH groups of tyrosine, or the imidazol group of histidine can also be used for binding. Figure 17.4 shows how the biocatalysts can be linked by a simple crosslinking process (Figure 17.4a) and also by co-crosslinking, in which inert molecules are incorporated in the high-polymer network in order to improve the mechanical and enzymatic immobilized preparation (Figure 17.4b).

The advantages and disadvantages of a given matrix must be taken into account when considering the appropriate procedure for a given enzyme immobilization. One advantage is the simplicity of the process. The main disadvantages are the fragility of the particles produced in some cases and diffusion limitations. Since crosslinking and co-crosslinking usually involve covalent bonds, immobilized biocatalysts in this way frequently undergo changes in the conformation with a resultant loss of activity. The isomerization of glucose process is a very important example of the industrial application using biocatalysts crosslinked with glutaraldehyde. Some of the immobilized preparations used in these large-scale processes are produced simply by glutaraldehyde treatment of bacterial cell masses that have formed fine particles. ${ }^{10}$

\subsubsection{Entrapment and Encapsulation}

The entrapment method for immobilization consists of the physical trapping of the active components into a film, gel, fiber, coating, or microencapsulation ${ }^{73}$ (see Figure 17.5). This method can be achieved by mixing an enzyme or active molecule with a polymer and then crosslinking the polymer to form a lattice structure that traps the enzyme. Microencapsulated enzymes are formed by enclosing enzymes solution within spherical semipermeable polymer membranes with controlled porosity.

While the encapsulation of dyes, drugs, and other chemicals has been known for some time, it was not until the mid-1960s that such a method was first applied to enzymes. Since that first report, a number of other enzymes have been successfully immobilized via microencapsulation, 
(a)

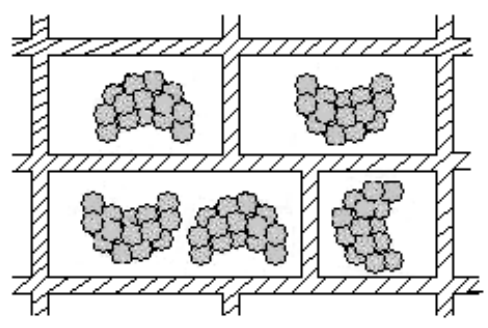

(b)

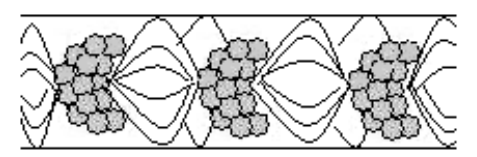

(c)

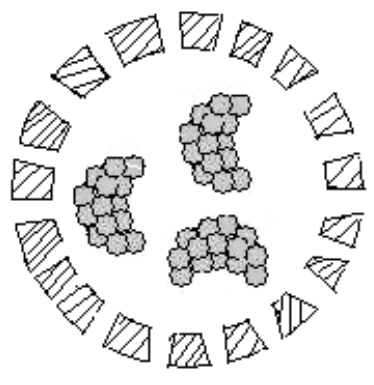

FIGURE 17.5 Enzyme encapsulation in a matrix (a), fiber (b), or capsule (c).

using a number of different materials and methods to prepare the microcapsules. The advantages of this immobilization method are the extremely large surface area between the substrate and the enzyme, within a relatively small volume, and the real possibility of simultaneous immobilization. The major disadvantages of this method include the occasional inactivation of enzyme during microencapsulation and the high enzyme concentration required. In addition, to retain the enzyme, the pore size needs to be very low and these systems tend to be very diffusion limited. ${ }^{72}$

\subsubsection{Protein Fusion to Affinity Ligands and Enzymatic Conjugation}

As described before, there are many methods for protein immobilization, but some of them require chemical modification of the matrix, which may result in material degradation, especially when biodegradable polymers are used. In addition, these modifications, necessary to attach the enzyme to the matrix, often result in the loss of enzyme activity as well as the inclusion of toxic organic compounds, which have to be removed before the system can be used in biomedical applications. In this type of application, the efficacy of immobilized biomolecules for stimulating specific cell responses (e.g., proliferation or differentiation) depends on the mode by which these modulators are presented to the target cells. In these cases, it is important to ensure the correct orientation and full bioactivity of the molecules when they are immobilized. Covalent binding by chemical coupling, again, might hinder ligand-receptor interaction or prevent receptor dimerization and capping on target cells.

In nature, there are certain protein molecules, such as lectins, ${ }^{14,82}$ avidin, ${ }^{83}$ immunoglobulin $\mathrm{G}$ (IgG) binding domains of protein $\mathrm{G}$ and protein $\mathrm{A},{ }^{84,85}$ and carbohydrate binding modules ${ }^{86,87}$ (present in many polysaccharide-degrading enzymes), that bind with high affinity and specifically to certain molecules or solid surfaces. These binding domains may be used as affinity tags for immobilizing proteins to affinity adsorbents. In this technique, DNA encoding a polypeptide affinity tag is fused to the gene of interest, and the expression of the gene results in a fusion protein. Such a fusion protein could be immobilized by the specific binding of the affinity tag to an affinity adsorbent (Figure 17.6a). With this method, the conformational changes in the protein upon immobilization are minimal, and the immobilized biomolecule could retain high activity. In addition, since fusion proteins are specifically immobilized on the support materials, these methods normally allow the immobilization of high densities of ligands and can also simplify the immobilization procedure.

The use of genetic engineering techniques to construct chimeric proteins, containing a functional domain displaying bioactivity together with an affinity domain, has proven to be a very useful approach for immobilizing biomolecules on solid materials. Several proteins, including 


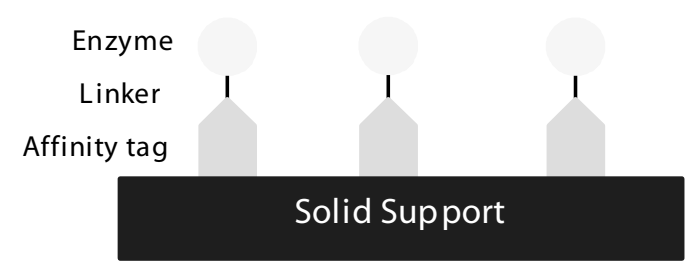

(a)

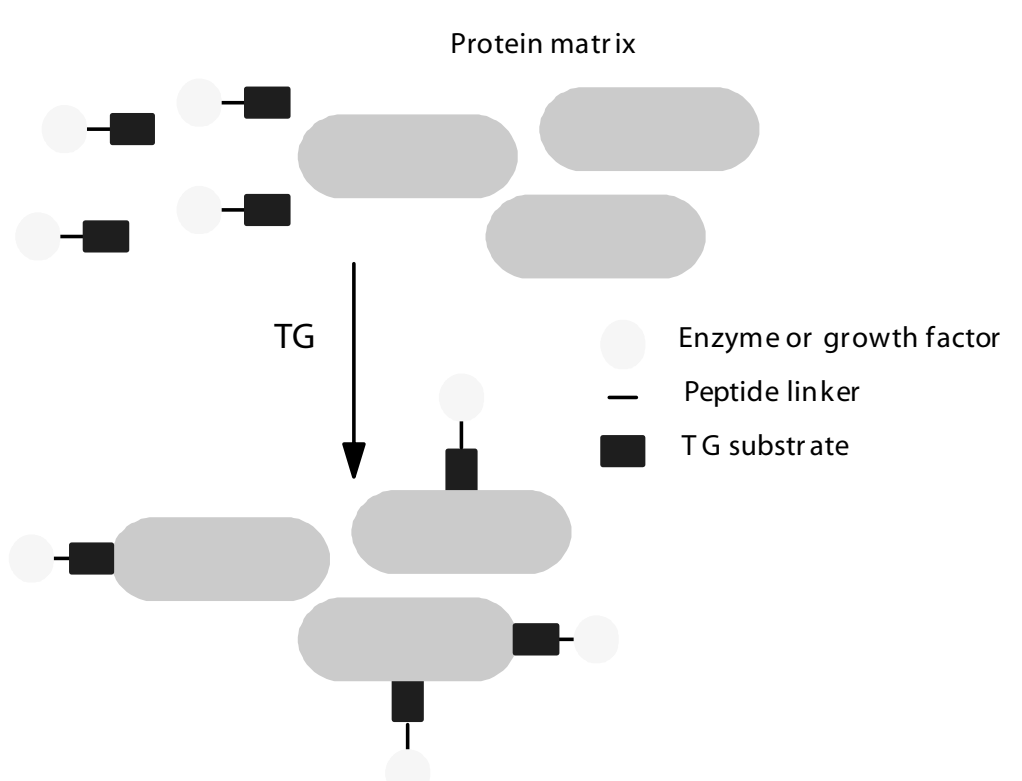

(b)

FIGURE 17.6 Enzyme immobilization to solid matrices via protein fusion to an affinity ligand (a) and enzymatic conjugation catalyzed by transglutaminase (b).

enzymes, ${ }^{53,88,89}$ antibodies, ${ }^{90,91}$ cytokines, ${ }^{92}$ and streptavidin,,${ }^{93}$ have been immobilized on the surface of cellulosic matrices by fusing genetically these proteins to cellulose-binding domains.

By using protein fusion techniques, bifunctional proteins can be prepared without changing their activity and binding properties..$^{53,87,89}$ This approach has found various applications in biotechnology, diagnostics, and medicine for the purification and immobilization of biologically active proteins. It can be used, for instance, to promote the attachment of several mammalian cells to different surfaces by fusing a variety of peptides, growth factors, and cytokines to a specific binding domain, and this might be useful for the activation and growth of progenitor cells in culture.

The binding affinity between streptavidin and biotin is among the strongest noncovalent bonds known to exist $\left(K_{D}=10^{-15} M\right) .{ }^{83}$ Therefore, the high affinity coupling of the biotin-avidin system has been used to immobilize different biomolecules on the surface of biomaterials and biosensors. ${ }^{94,95}$ It consists of using avidin as a bridge between the biotinylated surface and biotinylated short ligand molecules.

The immobilization of biomolecules on protein matrices may also be achieved via an enzymatic reaction catalyzed by transglutaminase (TG) enzyme. TG catalyzes the acyl transfer reaction between the $\gamma$-carboximine group of a peptide-bound glutaminyl residue and a primary amino group of various protein substrates. The result of this reaction is the formation of an irreversible crosslinked, insoluble supramolecular structure. ${ }^{96}$ In addition, TG can be used to bind glutamine- 
containing peptides or polypeptides to $\mathrm{NH}_{2}$ surfaces, ${ }^{69}$ and this methodology is schematically represented in Figure 17.6b. This approach was used by Sakiyama et al. ${ }^{97,98}$ to incorporate heparinbinding peptides and to design a growth factor delivery system. In the latter work, they developed a growth factor fusion protein, containing a bi-domain peptide consisting of a $\beta$-nerve growth factor $(\beta-N G F)$ and an exogenous factor XIIIa (substrate for enzymatic crosslinking). The fusion protein was covalently immobilized within a three-dimensional cell in-growth matrix based on fibrin using the transglutaminase activity of factor XIIIa.

\subsubsection{Enzyme Immobilization in Biomedical Applications}

Biomaterials can be combined with biomolecules, such as enzymes and growth factors, to yield biologically functional systems. There is a wide and diverse range of materials and methods available for enzyme immobilization on or within the biomaterial. The methods for immobilizing enzymes and other biomolecules are the same as described in Section 17.3.1 of this chapter, but the choice of the method depends largely on the final application. Furthermore, the criteria for selecting the immobilization methods should also take into account that the immobilized enzyme should retain an acceptable level of activity over a certain period of time in terms of economic or clinical aspects.

The methods used for the administration of immobilized enzymes may be divided into two principal groups 9 : immobilized enzymes that are intended for prolonged circulation and enzymes that must be necessarily present in different tissues and organs of the body. In the second case, the immobilized enzyme is intended for local deposition during the treatment of discrete lesions (e.g., thrombi, tumors, atherosclerotic injuries) or of the individual organs. ${ }^{9}$

Table 17.3 describes some examples of immobilized enzymes in various biomaterial supports for different biomedical applications.

\subsubsection{Biologically Functional Surfaces}

Biomaterials, especially when used in tissue engineering applications, must have the capacity to induce tissue regeneration/repair in order to achieve a more rapid recovery of the defect. At present, the existing scaffolds are not satisfactory in achieving rapid and full recovery of the defect. The attachment of cells to biomaterials, and their subsequent spreading, are mediated by extracellular matrix (ECM) glycoproteins such as fibronectin, collagen, etc. ECM glycoproteins contain short sequences with cell attachment properties, which interact with the integrin family of cell surface receptors. The peptide sequence Arg-Gly-Asp (RGD) has been identified as being capable of interacting with cell surface receptors. Thus, the immobilization of biologically active molecules on the surface of biomaterials for presenting effectors to target cells or to induce a particular effect is of great interest, since the immobilization of active agents presents the advantage of providing a continuous and localized stimulus for cell proliferation. Unlike nonimmobilized active agents, which are often consumed by cells, immobilized biomolecules remain bound to a substrate that is not consumed by cells and thus remain available to stimulate growth of additional cells. This is particularly useful in perfusion cultures in which growth medium is continuously added and removed to allow long-term cell proliferation.

Biodegradable polymers have been used as scaffolding materials for various tissue engineering applications because they can provide the support on which cells and tissues can adhere, but they can also guide and regulate the proliferation and activities of the adhered cells. However, the intrinsic hydrophobic property of some of these polymers ${ }^{108}$ restricts their applications as cell colonizing materials. Many methods have been used to modify the properties of polymer surface, such as plasma treatment-induced grafting polymerization, ozone oxidation, and immobilization of enzymes, and special biologically active agents have been used to introduce reactive groups onto polymeric surfaces. ${ }^{109}$ 


\section{TABLE 17.3 \\ Examples of Immobilized Enzymes in Various Biomaterials for Different Biomedical Applications}

\begin{tabular}{|c|c|c|c|c|}
\hline Enzyme & Biomaterial (Carrier) & $\begin{array}{l}\text { Immobilization } \\
\text { Method }\end{array}$ & Application & Ref. \\
\hline Alkaline phosphatase & $\begin{array}{l}\text { pHEMA }^{\mathrm{a}} \\
\text { Glassy carbon }\end{array}$ & $\begin{array}{l}\text { Entrapment } \\
\text { Protein fusion to } \\
\text { affinity tag }\end{array}$ & $\begin{array}{l}\text { Induction of bone and cartilage } \\
\text { mineralization } \\
\text { Biosensor/enzyme-linked } \\
\text { immunoassays }\end{array}$ & $\begin{array}{l}99 \\
95\end{array}$ \\
\hline$\alpha$-amylase & $\begin{array}{l}\text { pHEMA }^{\mathrm{a}} \\
\text { Starch polymeric blend }\end{array}$ & $\begin{array}{l}\text { Covalent binding } \\
\text { Encapsulation }\end{array}$ & $\begin{array}{l}\text { Fixed-bed reactor } \\
\text { Tailor the degradation rate of starch- } \\
\text { based biomaterials }\end{array}$ & $\begin{array}{l}100 \\
101\end{array}$ \\
\hline$\beta$-galactosidase & Gelatin & Encapsulation & Not specified & 102 \\
\hline Glucose oxidase & Proteins & $\begin{array}{l}\text { Enzymatic } \\
\text { conjugation }\end{array}$ & Biosensor & 69 \\
\hline$\alpha$-chymotrypsin & Cellophane & $\begin{array}{l}\text { Plasma modification/ } \\
\text { covalent binding }\end{array}$ & Not specified & 103 \\
\hline $\begin{array}{l}\text { Acetylcholinesterase } \\
\text { Choline oxidase }\end{array}$ & pHEMA $^{\mathrm{a}}$ & $\begin{array}{l}\text { Entrapment } \\
\text { Covalent binding } \\
\text { Ionic interactions }\end{array}$ & Biosensor & 104 \\
\hline Papain & $\begin{array}{l}\text { Polyethylene } \\
\text { Glass surfaces }\end{array}$ & $\begin{array}{l}\text { Plasma modification } \\
\text { Covalent binding }\end{array}$ & Not specified & 105 \\
\hline Lysozyme & $\begin{array}{l}\text { Gelatin and succinylated } \\
\text { gelatin } \\
\text { Poly(ethylene glycol)- } \\
\text { poly(aspartic acid) } \\
\text { copolymer }\end{array}$ & $\begin{array}{l}\text { Adsorption } \\
\text { Ionic interactions } \\
\text { Entrapment/ionic } \\
\text { binding }\end{array}$ & $\begin{array}{l}\text { Reduction of prosthetic valve } \\
\text { endocarditis } \\
\text { Delivery of lysozyme as a lytic } \\
\text { enzyme }\end{array}$ & 106 \\
\hline Heparinase & Sepharose & Covalent binding & $\begin{array}{l}\text { Bioreactor for extracorporeal } \\
\text { elimination of heparin from blood }\end{array}$ & 52 \\
\hline Phospholipase $\mathrm{A}_{2}$ & Agarose & Not mentioned & $\begin{array}{l}\text { Bioreactor for treatment of } \\
\text { hypercholesterolemia (reduce } \\
\text { plasma cholesterol) }\end{array}$ & 107 \\
\hline Bilirubin oxidase & Agarose & Covalent binding & $\begin{array}{l}\text { Bioreactor for removal of bilirubin } \\
\text { from blood }\end{array}$ & 61 \\
\hline $\begin{array}{l}\text { Prolidase } \\
\text { a Poly(2-hydroxy ethy } \\
\text { b Poly }(D, L \text {-lactide-co- }\end{array}$ & $\begin{array}{l}\text { PLGA }^{\mathrm{b}} \text { microspheres } \\
\text { methacrylate). } \\
\text { ycolide). }\end{array}$ & Encapsulation & Enzyme replacement therapy & 25 \\
\hline
\end{tabular}

Various strategies have been developed to incorporate bioactive agents on the surface of biomaterials for controlling cell and tissue responses. The immobilization process can be involved, enriching surfaces for enhancing the cellular adhesion. Biomolecules such as enzymes, antibodies, antigens, peptides, or drugs have been immobilized on or within polymeric systems. An example of an adhesive protein is fibronectin, which is able to promote cellular adhesion through binding to integrin receptors, and this interaction has also been shown to play a role in cell growth, differentiation, and overall regulation of cell function. ${ }^{77,110}$ Hern and Hubbell ${ }^{111}$ showed that the incorporation of the adhesion peptide RGD into a nonadhesive hydrogel proved to be useful for tissue resurfacing. There are numerous other adhesion peptides for targeting particularly desirable cell types and to modulate biological responses.

Urokinase has been widely used for the clinical treatment of thrombogenetic disease and hemorrhoidal disease. Artificial organ materials, on which urokinase was immobilized for its 
fibrinolytic activity, have been developed for blood-compatible materials. For example, Liu et al. ${ }^{55}$ immobilized urokinase by encapsulation in poly(2-hydroxyethyl methacrylate) and König et al. ${ }^{56}$ introduced urokinase on the surface of the polytetrafluoroethylene using plasma modification technique by covalent bond. Another example of immobilized urokinase application was reported by Kato and coworkers, ${ }^{54}$ who had used urokinase immobilized in a Teflon catheter for treatment of thrombosis.

Most of the studies found in the literature, regarding the surface functionalization of biomaterials with biological molecules, include the incorporation of adhesion and differentiation factors. The same approach may be used to incorporate specific enzymes able to regulate a number of cell functions. For instance, it is known that mitogen activated protein (MAP) kinase, upon activation by dual phosphorylation at threonine and tyrosine residues, is able to activate downstream targets that have been implicated in controlling gene expression, cell differentiation, and proliferation. ${ }^{12}$ This enzyme may be immobilized on the surface of biomaterials to control cell response, but other possibilities using different enzymes remain unexplored.

\subsubsection{Enzyme Delivery}

Although purified enzymes are now available for some enzyme deficiency diseases (see Table 17.1), there are many problems in delivering the enzyme to the required site under such conditions that it will remain stable and active for a reasonable time. Normally, quite large amounts of enzyme are necessary with high level of purity and in a nonimmunogenic form. ${ }^{9,14,113,114}$ In addition, many enzymes when administered are inactivated or degraded fairly rapidly. The delivery of therapeutic molecules requires, therefore, efficient strategies to have a precise control on their release profile according to specific locations. It might be possible to control the release of such molecules by creating delivery systems sensitive to changes in $\mathrm{pH}$, temperature, or salt concentration or to the feedback provided by cells. The concept of enzyme-activated drugs in therapy is scientifically, as well as clinically, attractive, as it allows the chemist and enzymologist full intellectual rein in designing interlinked systems. ${ }^{114}$ As therapeutic drugs, enzymes possess several attributes such as high specificity toward substrate, high solubility for preparing liquid formulations, and optimum activity under physiological conditions. ${ }^{115}$ The administration of enzymes, in cases of enzyme deficiency and inborn errors of metabolism and in the treatment of certain types of cancer, appears to offer a successful form of therapy. Cancer therapy based on the delivery of enzymes to tumor sites has advanced in several directions since antibody-directed enzyme/prodrug therapy was first described. ${ }^{116}$ Nanospheres, nanocapsules, liposomes, micelles, and other nanoparticulates are frequently referred to as carriers for delivery of therapeutic and diagnostics agents. ${ }^{113}$

Asparagine is an essential amino acid for certain types of leukemias that lack asparagines synthetase activity. The activity of $L$-asparaginase is to degrade asparagine into aspartate and ammonia. Therefore, asparaginase has been of interest to biochemists and clinicians as a possible cancer therapeutic agent. Some success has been achieved in administering asparaginase in capsules made of nylon and polyurea to mice and rats. Although asparaginase has been found to be effective in the treatment of some patients, ${ }^{117}$ it may have several serious side effects. ${ }^{41}$ Relatively high concentrations of the enzyme are needed for it to be clinically effective. These levels cause a wide range of toxic effects on several organs including the liver, pancreas, kidneys, and brain. The enzyme may also be recognized as foreign by the body and potentially severe immunogenic responses will be stimulated, resulting in hypersensitivity reactions. To overcome these problems, immobilized enzyme derivatives have been prepared on various supports for extracorporeal treatment (please see Section 17.3.2.3 of this chapter).

Enzymes may be also used in cancer therapy as prodrug activators. This therapy consists basically in using a drug that has been chemically modified so that it remains inactive until specifically activated by an enzyme at the target site. ${ }^{11}$ 
Another example of an anticancer enzyme is hyaluronidase. ${ }^{50}$ Hyaluronidase is a globular enzyme of endoglycosidase action, which can depolymerize hyaluronic acid in the organism, decreasing its viscosity and increasing tissue permeability. Hyaluronidase has been utilized extensively as an adjunct in anticancer chemotherapy regimens, suggesting that hyaluronidase has intrinsic anticancer properties against tumor growth. ${ }^{51}$ In vitro studies in tissue culture with tumor spheroids and in vivo tests using animal models demonstrated the beneficial effect of hyaluronidase for the penetration of drugs into tumor tissue. Later, in a prospective clinical trial, hyaluronidase significantly improved the outcomes of patients with bladder carcinoma if the enzyme was administrated topically together with mitomycin C. ${ }^{49,50}$ Hyaluronidase is also used for local application (subcutaneous injections) during treatment of joint disease, in dermatology, and in ophthalmology. ${ }^{48}$ Hyaluronidase had been used in ophthalmology with the aim of formation of a thinner scar and to prevent necrosis after paravataes with zytostatics.

Trypsin has also been used to remove dead tissue from wounds, burns, and ulcers to speed the growth of new tissue and skin grafts, as well as to inhibit the growth of some contaminant organisms. The inappropriate activation of trypsinogen within the pancreas leads to development of pancreatitis. ${ }^{47}$ Once trypsin is activated, it is capable of activating many other digestive pro-enzymes. These activated pancreatic enzymes further enhance the auto-digestion of the pancreas. Many materials, such as nylon, polysulfone, glycidyl methacrylate, chitosan, cellulose, and cellulose derivatives, have been used for trypsin immobilization..$^{44,46,47}$

Enzyme therapy has also been tested for pancreatic insufficiency and cystic fibrosis. Pancreatic insufficiency can be alleviated by administrating orally enteric-coated microspheres containing lipase, amylase, and proteases. A special polymer coating protects the enzymes at low $\mathrm{pH}$, such as in the stomach, and then releases them in the intestine at physiological $\mathrm{pH}^{11,14}$

Lysozyme is a good example of an enzyme that catalyzes chemical reactions in the cell. Lysozyme acts to kill bacteria by cleaving the covalent bond between the alternating polysaccharides that compose peptidoglycan in bacterial cell walls. ${ }^{27}$ The human salivary defense proteins and lysozyme are known to exert a wide antimicrobial activity against a number of bacterial, viral, and fungal pathogens in vitro. Therefore, these proteins, alone or in combinations, have been incorporated as preservatives in foods and pharmaceuticals as well as in oral health care products to restore saliva's own antimicrobial capacity in patients with dry mouth. These antimicrobials used in oral health care products, such as dentifrices, mouth rinses, moisturizing gels, and chewing gums, have been purified from bovine colostrum. Other studies had been reported with lysozyme bound to chitosan, silica gel by means of physical adsorption, crosslinking to a polystyrene divinylbenzene matrix by the formation of ionic bindings, and by covalent attachment to nonporous glass beads. ${ }^{29}$ Harada and Kataoka ${ }^{28}$ described lysozyme immobilized into poly(ethylene glycol)-poly(aspartic acid) micelle. Lysozyme was selected as a model protein to incorporate into the micelle because it has a high isoelectric point ( $\mathrm{pI}=11$ ), is positively charged over a wide range of $\mathrm{pH}$, and has practical usage in drug delivery application as a lytic enzyme. Chen and Chen ${ }^{118}$ prepared immobilized lysozyme by carbodiimide method to form amide bonds with an enteric coating polymer (hydroxypropyl methyl-cellulose acetate succinate [AS-L]) as the carrier, which shows reversibly soluble-insoluble characteristics with $\mathrm{pH}$ changes.

The glucose-6-phosphate dehydrogenase enzyme catalyzes the oxidation of glucose-6-phosphate to 6-phosphogluconate while concomitantly reducing the oxidized form of nicotinamide adenine dinucleotide phosphate $\left(\mathrm{NADP}^{+}\right)$to nicotinamide adenine dinucleotide phosphate (NADPH). NADPH, a required cofactor in many biosynthetic reactions, maintains glutathione in its reduced form. Reduced glutathione acts as a scavenger for dangerous oxidative metabolites in the cell. With the help of the enzyme glutathione peroxidase, reduced glutathione also converts harmful hydrogen peroxide to water. Red blood cells rely heavily on glucose-6-phosphate dehydrogenase activity because it is the only source of NADPH that protects the cells against oxidative stresses. People deficient in glucose-6-phosphate dehydrogenase are not prescribed, therefore, with oxidative drugs because their red blood cells undergo rapid hemolysis under this stress. ${ }^{36}$ In 
Greece, glucose-6-phosphate dehydrogenase deficiency is the main cause of severe neonatal jaundice. The deficiency of this enzyme affects all races; the highest prevalence is among persons of African, Asian, or Mediterranean descent. ${ }^{37}$ Study of immobilized glucose-6-phosphate dehydrogenase has been reported. Kotorman et al. ${ }^{38}$ immobilized glucose-6-phosphate dehydrogenase from yeast on polyacrylamide beads possessing carboxylic functional groups activated by a watersoluble carbodiimide. They verified highest operational stability of immobilized glucose-6-phosphate dehydrogenase.

In relation to the use of immobilized enzymes with therapeutic purposes, catalase is one of the most interesting because it is employed to accelerate healing as well as to correct hereditary deficiencies and, in combination with hydrogen peroxide, as an antiseptic against anaerobes. ${ }^{33,34}$ The catalase enzyme has the ability to decompose hydrogen peroxide into oxygen and water, playing a central role in controlling the hydrogen peroxide concentration in human cells. More than $98 \%$ of blood catalase is localized in erythtocytes. ${ }^{119}$ These cells, with their high catalase level, provide a general protection against the toxic concentration of this small hydrogen peroxide molecule. The deficiency of catalase could cause acatalasemia. ${ }^{35,119}$ Several methods have been developed for the immobilization of catalase. ${ }^{1,74,120}$ Immobilization is often accompanied by changes in the enzymatic activity, optimum $\mathrm{pH}$, affinity to the substrate, and stability. The extent of these changes depends on the enzyme, carrier support, and the immobilization conditions. ${ }^{121}$ The shift in the optimum $\mathrm{pH}$, from acidic or alkaline to neutral $\mathrm{pHs}$, may be useful for biomedical applications since it will allow the use of some enzymes (more active at low or high pHs) under more physiological conditions.

The approach developed by Sakiyama-Elbert et al. ${ }^{98}$ consisting in a cell-triggered growth factor delivery system, may also be used for the release of other important therapeutic molecules.

\subsubsection{Bioreactors for Extracorporeal Enzyme Therapy}

Extracorporeal shunts have been proposed ${ }^{72,122}$ for the treatment of several clinical conditions. The most likely applications for enzymatic treatment are the removal of urea during kidney failure, removal of toxins (e.g., paracetamol) during liver failure, or the reduction of key metabolites from the circulation to treat cancer.

Urease is one of the most important enzymes in biomedical applications. Urease is an enzyme that catalyzes the hydrolysis of urea to form ammonia and carbon dioxide. Urea is one of the main metabolic end products, and the removal of its excess has been a major problem for patients suffering from renal failure. Hence, its immobilization by entrapment has been investigated by many workers for applications in biosensors and as artificial kidneys. The most attention has been given to the development of enzyme reactors, where the urea would be removed and the dialysis fluid prepared for further use. ${ }^{30,31}$ The use of this enzyme is often limited due to its high cost, availability in small amounts, instability, and the limited possibility of feasible recovery of these biocatalysts from a reaction mixture. Numerous synthetic and natural polymeric supports have been used for urease immobilization, and their uses in medical and technical fields are well reported. The covalent bond of urease in different supports has been reported in many studies. Some commonly used supports are chitosan-poly(glycidil methacrylate), carboxymethylcellulose, polyurethane, sepharose-2B, polyacrylamide, ion exchange resins, copolymers of polyglycidylmethacrylate, calcium alginate beads, poly(vinyl alcohol) (PVA), hydroxyapatite, 2-dimethylaminoethylmethacrylate, poly(ethylene glycol dimethacrylate/2-hydroxy ethylene methacrylate) microbeads, poly(caprolactone)/starch, and poly(orthoesters). . $^{32,109,123-125}$

As mentioned before in Section 17.3.2.2 of this chapter, $L$-asparaginase has been used for treating leukemias and disseminating cancers that require asparagines for growth, but this treatment presents several serious side effects. To overcome these problems, immobilized enzyme derivatives have been prepared on various supports for extracorporeal treatment. Blood can be passed over the immobilized enzyme, thus depleting the asparagine supply needed by the cancer cells. The enzyme does not come into direct contact with the organs to which it is toxic, and hypersensitivity 
reactions do not occur. With this type of treatment, however, the blood plasma must be first separated from the cells to minimize cell damage and then passed through a separate column containing the immobilized enzyme. This process requires that the blood remain outside the body for relatively long periods of time, resulting in the denaturation and depletion of many plasma proteins. ${ }^{41,42}$ Some techniques have been developed to minimize this problem, such as the use of a porous hollow-fiber plasmapheresis device. With this system, the plasma can be separated from the whole blood and contact with immobilized enzyme in one passage, thus minimizing its time outside the body and then reducing the damage to the plasma proteins. Adsorption techniques have been used to immobilize asparaginase onto hollow fibers after first coating the fibers with albumin and then crosslinking the enzyme with glutaraldehyde. ${ }^{41,126}$ Maciel and Minim ${ }^{43}$ also reported that the use of $L$-asparaginase covalently attached to nylon tubing may constitute a useful system to be used in clinical applications.

Bilirubin oxidase is also an example of enzyme used in extracorporeal applications. ${ }^{61}$ All human newborns accumulate bilirubin to levels greater that those in adults, and $20 \%$ accumulate enough to stain their skin, resulting in jaundice. Bilirubin binds to cellular and mitochondrial membranes, causing cell death in a variety of tissues. Clinically, bilirubin toxicity may lead to mental retardation, cerebral palsy, deafness, seizures, or death. The most common treatments for jaundiced infants are phototherapy and exchange transfusion. This technique presents serious problems such as hypoglycemia, hypocalcemia, acidosis, transmission of infectious, etc. Lavin et al. ${ }^{61}$ reported the use of a highly specific enzyme to remove bilirubin from the bloodstream using a small reactor (extracorporeal circuit) containing bilirubin oxidase covalently immobilized in agarose beads. These researchers obtained good results for the removal of the bilirubin in humans and in genetically jaundiced rats.

Heparinase, an enzyme that degrades heparin into small polysaccharides, has also been immobilized into an extracorporeal device (artificial kidney bioreactor) to eliminate the anticoagulant properties of heparin (used to prevent clotting in the device) before the blood returns to the patient. ${ }^{52}$

\subsubsection{Diagnostic Assays and Biosensors}

Isolated or combined enzymes are being used in medicine as useful tools for clinical analysis. About 50 different enzymes are used in different aspects of clinical diagnoses, and for most of these, much higher levels of purity are required than for most industrial enzymes. Two of the major enzymes used are peroxidase from horseradish and alkaline phosphatase from beef intestinal mucosa, both being required for immunoassays. The enzymes may be used in test strips, ELISA, biosensors, and autoanalyzers. ${ }^{11}$

The serum uric acid concentration is an important index for clinical diagnosis of gout, leukemia, toxemia of pregnancy, and severe renal impairment. ${ }^{127}$ A number of enzymes are assayed in serum and urine for diagnostic purposes; the more frequently used ones are discussed below.

Alkaline phosphatases (ALP) are a group of enzymes found primarily in the liver (isoenzyme ALP-1) and bone (isoenzyme ALP-2). There are also small amounts produced by cells lining the intestines (isoenzyme ALP-3), the placenta, and the kidney (in the proximal convoluted tubules). What is measured in the blood is the total amount of alkaline phosphatase released from these tissues into the blood. As the name implies, this enzyme works best at an alkaline $\mathrm{pH}(\mathrm{pH} 10)$, and thus the enzyme itself is inactive in the blood. Alkaline phosphatase acts by splitting off phosphorus (an acidic mineral), creating an alkaline $\mathrm{pH}$. The primary importance of measuring alkaline phosphatase is to check the possibility of bone or liver diseases. ${ }^{128}$

Another application of immobilized enzymes is the development of improved sensing devices. ${ }^{9}$ Because of their high specificity for given substances, enzymes and monoclonal antibodies are particularly suitable for use as sensors. ${ }^{129}$ The membrane-covered electrode described by Clark in 1959 is the dominating sensor for the measurement of dissolved oxygen. ${ }^{130}$ Numerous modifications of the original concept have been developed. For instance, biosensors using enzymes have been used to detect the presence of various organic compounds, and recent developments have proven 
to be both rapid and highly selective. They have been used in important applications such as in clinical laboratories, fermentation processes, and pollution monitoring. ${ }^{131}$ Most of them have used a free or immobilized enzyme and an ion-sensitive electrode that measures indirectly (e.g., by temperature or color changes produced by an enzymatic reaction) the presence of a product whose formation is catalyzed by the enzyme. The biosensors usually have immobilized biological molecules attached to the surface of a transducer that allows an electronic or optical signal to be converted into an appropriate signal. This type of biosensor could be used to measure glucose, sucrose, lactose, $L$-lactate, galactose, $L$-glutamate, $L$-glutamine, choline, ethanol, methanol, hydrogen peroxide, starch, uric acid, etc., by using specific enzymes. ${ }^{31,127}$

Glucose oxidase is normally used to assay glucose concentration. Glucose sensors are the biosensors that have attracted much interest in both research and applications fields. One particularly important medical application of improved biosensors could be in the treatment of diabetic patients for whom proper levels of insulin and glucose must be maintained. For instance, small implantable devices for sampling blood to determine the levels of glucose and regulate the delivery of insulin could be developed using this enzyme. ${ }^{39}$ A great variety of immobilization methods (e.g., encapsulation, entrapment) and transducers have been developed to construct the glucose sensors with better performance and practicability since the work of Clark and Lyons in $1962 .{ }^{40}$ Several materials have been used, such as polyethylene terephthalate (PET), polyacrylamide, $N$ - isopolyacrylamide, sol-gel, poly(2-hydroxyethyl methacrylate), alginate, artificial resins, glass, etc. ${ }^{31,78,132}$

For example, Zhang and Cass ${ }^{133}$ have also immobilized alkaline phosphatase on a nanoporous nickel-titanium film for sensor applications.

A number of other enzymes have been described with great potential for medical applications, including carboxypeptidases, collagenase, fibrinolysin, pepsin, ${ }^{44}$ streptokinase,${ }^{45}$ subtilisin, thrombin, tissue plasminogen activator, $\alpha$-amylase, $\alpha$-galactosidase, glucoamylase, lactase (-galactosidase), pectinase, pancreatin, phospholipases, cholesterol esterase and other DNases, RNases, phosphatases, esterases, sulfatases, isomerases, glucose isomerase, superoxide dismutase, cholesterol esterease, creatine kinase, and penicillin acylase. ${ }^{45,58,114,134-136}$

\subsubsection{Advantages and Disadvantages of Immobilized Enzymes}

The use of immobilized enzymes normally offers several advantages over free enzymes, such as increased stability, localization, and retention of the molecules at the material surface, which enables easier handling, repeated use, and decreased cost. Other important advantages of using therapeutic immobilized enzymes are the prolonged blood circulation lifetime without the loss of specific activity ${ }^{9}$ and the lower immunogenicity. ${ }^{11,137}$ This advantage is particularly important for delivering enzymes or other biomolecules and may constitute an alternative and suitable method for the enzyme replacement therapy. However, some limitations have been attributed to the use of immobilized enzymes in biomedical applications, such as mass transfer resistances (substrate in and product out), adverse biological responses of enzyme support surfaces (in vivo or ex vivo), fouling by other biomolecules, greater potential for product inhibition, and sterilization difficulties. ${ }^{126,137}$ Although the preparation of sterile immobilized enzyme systems may be complex, sterilization may be achieved by filtrating all the reagents and protein solutions through $0.2-\mu \mathrm{m}$ filters and working under aseptic conditions.

A very important issue regarding the use of enzymes or other products derived from biological or biotechnological processes in medical applications is to ensure that these therapeutic products do not contain any pyrogenic material, toxins, or infectious agents able to cause harmful effects. ${ }^{138}$ For that, it is necessary to perform a complete examination of the products to test their safety in terms of local tolerance, toxicity, carcinogenicity, and immunogenicity, among other pharmacological safety tests. ${ }^{138,139}$ Taking into account the diversity in the range of products and the uncertainty about the regulatory status of some of them, it is necessary to design safety evaluation programs to provide useful information to the responsible of clinical trials and to ensure patient safety. 


\subsection{CONCLUSIONS AND FUTURE PERSPECTIVES}

Enzyme instability, combined with the high cost associated with their isolation and purification, had been restricting the general use of therapeutic enzymes on a clinical basis. With the advances made in recombinant DNA technology, it is possible, by means of using adequate expression systems, to put available in larger quantities many enzymes, both for the assay of metabolites and for enzyme replacement therapy. The immobilization of enzymes on support materials had contributed largely to the success of diagnosis and enzyme therapy approaches.

The recent progress in biological science had revealed many types of therapeutic proteins able to regulate various cell functions. On the other hand, the development of new immobilization strategies, such as selective immobilization of proteins to self-assembled monolayers presenting active site-directed capture ligands ${ }^{140}$ or protein immobilization within specific locations (protein patterning), ${ }^{82}$ may constitute the basis of future immobilization methods. This is particularly important for biomedical applications where it is necessary to control the densities of immobilized proteins, the binding strength, and, most important, their binding orientation. The success of therapeutic agent delivery strategies will be mainly dependent on the developments in these research fields.

\section{ACKNOWLEDGMENTS}

S. A. Costa and H. S. Azevedo thank the Portuguese Foundation for Science and Technology for providing them postdoctoral scholarships SFRH/BPD/8469/2002 and SFRH/BPD/5744/2001, respectively. This work was partially supported by FCT Foundation for Science and Technology, through funds from the POCTI and/or FEDER programs.

\section{REFERENCES}

1. Cetinus, S.A. and Oztop, H.N., Immobilization of catalase into chemically crosslinked chitosan beads, Enzyme Microb. Technol., 32, 889, 2003.

2. Costa, S.A. et al., Studies of stabilization of native catalase using additives, Enzyme Microb. Technol., 30, 387, 2002.

3. Matsumoto, M. et al., Effects of polyols and organic solvents on thermostability of lipase, J. Chem. Technol. Biotechnol., 70, 188, 1997.

4. O'Fagain, C., Enzyme stabilization - recent experimental progress, Enzyme Microb. Technol., 33, 137, 2003.

5. Khajeh, K. et al., Chemical modification of bacterial alpha-amylases: changes in tertiary structures and the effect of additional calcium, Biochim. Biophys. Acta - Protein Struct. Mol. Enzymol., 1548, 229, 2001.

6. Minshull, J. et al., Engineered protein function by selective amino acid diversification, Methods, 32, 416, 2004.

7. Bilkova, Z. et al., Oriented immobilization of chymotrypsin by use of suitable antibodies coupled to a nonporous solid support, J. Chromatogr. A, 852, 141, 1999.

8. Fagain, C.O., Understanding and increasing protein stability, Biochim. Biophys. Acta, 1252, 1, 1995.

9. Torchilin, V.P., Immobilised enzymes as drugs, Adv. Drug Del. Rev., 1, 41, 1987.

10. Kennedy, J.F., Handbook of enzyme technology, in Principles of Immobilization of Enzymes, 3rd ed., Wiseman, A., Ed., Prentice Hall Ellis Harwood, New York, 1995, p. 235.

11. Price, N.C. and Stevens, L., Fundamentals of Enzymology. The Cell and Molecular Biology of Catalytic Proteins, 3rd ed., Oxford University Press Inc., New York, 1999.

12. Kellems, R.E. et al., Adenosine deaminase deficiency and severe combined immunodeficiencies, $T I G$, October, 278, 1985.

13. Tager, J.M., Biosynthesis and deficiency of lysosomal-enzymes, Trends Biochem. Sci., 10, 324, 1985. 
14. Poznansky, M.J., Enzyme-protein conjugates: new possibilities for enzyme therapy, Pharmacol. Ther., 21, 53, 1983.

15. Goldberg, D.M., Enzymes as agents for the treatment of disease, Clin. Chim. Acta, 206, 45, 1992.

16. Bailey, J.E. and Ollis, D.F., Biochemical Engineering Fundamentals, 2nd ed., McGraw-Hill, Singapore, 1986.

17. Das, A.K. et al., Biochemical analysis of mutations in palmitoyl-protein thioesterase causing infantile and late-onset forms of neuronal ceroid lipofuscinosis, Hum. Mol. Genet., 10, 1431, 2001.

18. de Grey, A.D., Bioremediation meets biomedicine: therapeutic translation of microbial catabolism to the lysosome, Trends Biotechnol., 20, 452, 2002.

19. Lund, P.M., Distribution of oculocutaneous albinism in Zimbabwe, J. Med. Genet., 33, 641, 1996.

20. Nakamura, E. et al., A novel mutation of the tyrosinase gene causing oculocutaneous albinism type 1 (OCA1), J. Dermatol. Sci., 28, 102, 2002.

21. Weng, Y.H. et al., Hyperbilirubinemia in healthy neonates with glucose-6-phosphate dehydrogenase deficiency, Early Hum. Dev., 71, 129, 2003.

22. Vulliamy, T. et al., The molecular basis of glucose-6-phosphate dehydrogenase deficiency, Trends Genet., 8, 138, 1992.

23. Schulpis, K.H. et al., The effect of neonatal jaundice on biotinidase activity, Early Hum. Dev., 72, $15,2003$.

24. Nyhan, W.L., Multiple carboxylase deficiency, Int. J. Biochem., 20, 363, 1988.

25. Genta, I. et al., Enzyme loaded biodegradable microspheres in vitro ex vivo evaluation, J. Control. Rel., 77, 287, 2001.

26. Brewerton, L.J. et al., Polyethylene glycol-conjugated adenosine phosphorylase: development of alternative enzyme therapy for adenosine deaminase deficiency, Biochim. Biophys. Acta, 1637, 171, 2003.

27. Brouwer, J. et al., Determination of lysozyme in serum, urine, cerebrospinal-fluid and feces by enzymeimmunoassay, Clin. Chim. Acta, 142, 21, 1984.

28. Harada, A. and Kataoka, K., Novel polyion complex micelles entrapping enzyme molecules in the core: Preparation of narrowly-distributed micelles from lysozyme and poly(ethylene glycol)poly(aspartic acid) block copolymer in aqueous medium, Macromolecules, 31, 288, 1998.

29. Crapisi, A. et al., Enhanced microbial cell-lysis by the use of lysozyme immobilized on different carriers, Process Biochem., 28, 17, 1993.

30. Higa, O.Z. and Kumakura, M., Preparation of polymeric urease discs by an electron beam irradiation technique, Biomaterials, 18, 697, 1997.

31. Karube, I. and Nomura, Y., Enzyme sensors for environmental analysis, J. Mol. Catal. B - Enzym., 10, 177, 2000.

32. Ayhan, F. et al., Optimization of urease immobilization onto non-porous HEMA incorporated poly(EGDMA) microbeads and estimation of kinetic parameters, Biores. Technol., 81, 131, 2002.

33. Akertek, E. and Tarhan, L., Characterization of immobilized catalases and their application in pasteurization of milk with H2o2, Appl. Biochem. Biotechnol., 50, 291, 1995.

34. Emerson, D. et al., A catalase microbiosensor for detecting hydrogen peroxide, Biotechnol. Tech., 10, 673, 1996.

35. Goth, L., A novel catalase mutation (a G insertion in exon 2) causes the type B of the Hungarian acatalasemia, Clin. Chim. Acta, 311, 161, 2001.

36. Zaitseva, E.A. et al., Stabilization mechanism of glucose-6-phosphate dehydrogenase, Biocatalysis, 41, 127, 2000.

37. Reclos, G.J. et al., Evaluation of glucose-6-phosphate dehydrogenase activity in two different ethnic groups using a kit employing the haemoglobin normalization procedure, Clin. Biochem., 36, 393, 2003.

38. Kotorman, M. et al., Coenzyme production using immobilized enzymes. III. Immobilization of glucose-6-phosphate dehydrogenase from bakers' yeast, Enzyme Microb. Technol., 16, 974, 1994.

39. Traitel, T. et al., Characterization of glucose-sensitive insulin release systems in simulated in vivo conditions, Biomaterials, 21, 1679, 2000.

40. Eggins, B., Biosensor: An Introduction, John Wiley \& Sons, New York, 1999.

41. Gombotz, W. et al., Immobilized enzymes in blood-plasma exchangers via radiation grafting, Radiat. Phys. Chem., 25, 549, 1985. 
42. Stecher, A.L. et al., Stability of L-asparaginase: an enzyme used in leukemia treatment, Pharm. Acta Helv., 74, 1, 1999.

43. Maciel, R. and Minim, L.A., Adaptive control of an open tubular heterogeneous enzyme reactor for extracorporeal leukaemia treatment, J. Process Control, 6, 317, 1996.

44. Bolte, G. et al., Peptic-tryptic digests of gliadin: Contaminating trypsin but not pepsin interferes with gastrointestinal protein binding characteristics, Clin. Chim. Acta, 247, 59, 1996.

45. Koneracka, M. et al., Direct binding procedure of proteins and enzymes to fine magnetic particles, $J$. Mol. Catal. B - Enzym., 18, 13, 2002.

46. Guo, W. and Ruckenstein, E., Crosslinked mercerized cellulose membranes for the affinity chromatography of papain inhibitors, J. Membr. Sci., 197, 53, 2002.

47. Hirota, M. et al., Significance of trypsin inhibitor gene mutation in the predisposition to pancreatitis, Int. Congr. Ser., 1255, 41, 2003.

48. Maksimenko, A.V. et al., Chemical modification of hyaluronidase regulates its inhibition by heparin, Eur. J. Pharm. Biopharm., 51, 33, 2001.

49. Pillwein, K. et al., Hyaluronidase additional to standard chemotherapy improves outcome for children with malignant brain tumors, Cancer Lett., 131, 101, 1998.

50. St. Croix, B. et al., Reversal of intrinsic and acquired forms of drug resistance by hyaluronidase treatment of solid tumors, Cancer Lett., 131, 35, 1998.

51. Lin, G. and Stern, R., Plasma hyaluronidase (Hyal-1) promotes tumor cell cycling, Cancer Lett., 163, 95, 2001.

52. Langer, R. et al., An enzymatic system for removing heparin in extracorporeal therapy, Science, 217 , 261, 1982.

53. Shpigel, E. et al., Immobilization of recombinant heparinase I fused to cellulose-binding domain, Biotechnol. Bioeng., 65, 17, 1999.

54. Kato, H. et al., External venous shunt as a solution to venous thrombosis in microvascular surgery, Br. J. Plast. Surg., 54, 164, 2001.

55. Liu, L.S. et al., Biological-activity of urokinase immobilized to cross-linked poly(2-hydroxyethyl methacrylate), Biomaterials, 12, 545, 1991.

56. König, U. et al., Plasma modification of polytetrafluoroethylene for immobilization of the fibrinolytic protein urokinase, Surf. Coat. Technol., 119, 1011, 1999.

57. Miller, J.M. et al., Streptokinase and streptodornase in the treatment of surgical infections, Lancet, 261, 220, 1953.

58. Dempfle, C.E. et al., Plasminogen activation without changes in tPA and PAI-1 in response to subcutaneous administration of ancrod, Thromb. Res., 104, 433, 2001.

59. Xu, Y. et al., Diverse roles of conserved asparagine-linked glycan sites on tyrosinase family glycoproteins, Exp. Cell Res., 267, 115, 2001.

60. Chen, T.H. et al., Enzyme-catalyzed gel formation of gelatin and chitosan: potential for in situ applications, Biomaterials, 24, 2831, 2003.

61. Lavin, A. et al., Enzymatic removal of bilirubin from blood: a potential treatment for neonatal jaundice, Science, 230, 543, 1985.

62. Hartmeier, W., Immobilized Biocatalysts: An Introduction, Springer-Verlag, Berlin, 1988.

63. Kragl, U., Immobilized enzymes and membrane reactor, in Industrial Enzymology, Godfrey, T. and Wet, S., Eds., Macmillan Press, London, 1996.

64. Swaisgood, H.E., Immobilized enzymes: Applications to bioprocessing of food, in Food Enzymology, Fox, P.F., Ed., Elsevier Science Publishers LTD, Essex, 1991.

65. Yang, Y. et al., Covalent bonding of collagen on poly(L-lactic acid) by gamma irradiation, Nucl. Instrum. Meth. Phys. Res. Sect. B - Beam Interact. Mater. Atoms, 207, 165, 2003.

66. Oswald, P.R. et al., Properties of a thermostable beta-glucosidase immobilized using tris(hydroxymethyl)phosphine as a highly effective coupling agent, Enzyme Microb. Technol., 23, 14, 1998.

67. Dybko, A. et al., Efficient reagent immobilization procedure for ion-sensitive optomembranes, Sens. Actuat. B-Chem., 39, 207, 1997.

68. Puleo, D.A. et al., A technique to immobilize bioactive proteins, including bone morphogenetic protein-4 (BMP-4), on titanium alloy, Biomaterials, 23, 2079, 2002.

69. Josten, A. et al., Enzyme immobilization via microbial transglutaminase: a method for the generation of stable sensing surfaces, J. Mol. Catal. B-Enzym., 7, 57, 1999. 
70. Akgol, S. et al., Immobilization of catalase via adsorption onto L-histidine grafted functional pHEMA based membrane, J. Mol. Catal. B - Enzym., 15, 197, 2001.

71. de Oliveira, P.C. et al., Immobilisation studies and catalytic properties of microbial lipase onto styrenedivinylbenzene copolymer, Biochem. Eng. J., 5, 63, 2000.

72. Rosevear, A. et al., Immobilized Enzymes and Cells, Adam Hilger, Philadelphia, 1987.

73. Bickerstaff, G.F., Enzymes in Industry and Medicine, Cambridge University Press, UK, 1991.

74. Solas, M.T. et al., Ionic adsorption of catalase on bioskin - kinetic and ultrastructural studies, $J$. Biotechnol., 33, 63, 1994.

75. Torres, R. et al., Reversible immobilization of invertase on Sepabeads coated with polyethyleneimine: Optimization of the biocatalyst's stability, Biotechnol. Prog., 18, 1221, 2002.

76. Chae, H.J. et al., Optimization of protease immobilization by covalent binding using glutaraldehyde, Appl. Biochem. Biotechnol., 73, 195, 1998.

77. Quirk, R.A. et al., Poly(L-lysine)-GRGDS as a biomimetic surface modifier for poly(lactic acid), Biomaterials, 22, 865, 2001.

78. Arica, Y. and Hasirci, V.N., Immobilization of glucose-oxidase in poly(2-hydroxyethyl methacrylate) membranes, Biomaterials, 8, 489, 1987.

79. Harold, E.S., Immobilized enzymes: applications to bioprocessing of food enzymology, in Food Enzymology, Fox, P.F., Ed., Elsevier Applied Science, New York, 1991, p. 322.

80. Eldin, M.S.M. et al., Immobilization of penicillin G acylase onto chemically grafted nylon particles, J. Mol. Catal. B - Enzym., 10, 445, 2000.

81. Albayrak, N. and Yang, S.T., Immobilization of beta-galactosidase on fibrous matrix by polyethyleneimine for production of galacto-oligosaccharides from lactose, Biotechnol. Prog., 18, 240, 2002.

82. Blawas, A.S. and Reichert, W.M., Protein patterning, Biomaterials, 19, 595, 1998.

83. Clare, D.A. et al., Molecular design, expression, and affinity immobilization of a trypsin-streptavidin fusion protein*(1), Enzyme Microb. Technol., 28, 483, 2001.

84. Kondo, A. and Teshima, T., Preparation of immobilized enzyme with high-activity using affinity tag based on protein-a and protein-G, Biotechnol. Bioeng., 46, 421, 1995.

85. Shpigel, E. et al., Expression, purification and applications of staphylococcal protein A fused to cellulose-binding domain, Biotechnol. Appl. Biochem., 31, 197, 2000.

86. Boraston, A.B. et al., Carbohydrate-binding modules: Diversity of structure and function, in Recent Advances in Carbohydrate Bioengineering, Svenson, B., Ed., The Royal Society of Chemistry, Cambridge, 1999, p. 202.

87. Kobatake, E. et al., Production of the chimeric-binding protein, maltose-binding protein-protein A, by gene fusion, J. Biotechnol., 38, 263, 1995.

88. Ong, E. et al., Enzyme immobilization using a cellulose-binding domain: properties of a betaglucosidase fusion protein, Enzyme Microb. Technol., 13, 59, 1991.

89. Richins, R.D. et al., Expression, immobilization, and enzymatic characterization of cellulose-binding domain-organophosphorus hydrolase fusion enzymes, Biotechnol. Bioeng., 69, 591, 2000.

90. Berdichevsky, Y. et al., Matrix-assisted refolding of single-chain Fv-cellulose binding domain fusion proteins, Protein Expr. Purif., 17, 249, 1999.

91. Reinikainen, T. et al., Comparison of the adsorption properties of a single-chain antibody fragment fused to a fungal or bacterial cellulose-binding domain, Enzyme Microb. Technol., 20, 143, 1997.

92. Doheny, J.G. et al., Cellulose as an inert matrix for presenting cytokines to target cells: production and properties of a stem cell factor-cellulose-binding domain fusion protein, Biochem. J., 339, 429, 1999.

93. Le, K.D. et al., A streptavidin-cellulose-binding domain fusion protein that binds biotinylated proteins to cellulose, Enzyme Microb. Technol., 16, 496, 1994.

94. Cannizzaro, S.M. et al., A novel biotinylated degradable polymer for cell-interactive applications, Biotechnol. Bioeng., 58, 529, 1998.

95. Zhang, J.K. and Cass, A.E.G., Electrochemical analysis of immobilised chemical and genetic biotinylated alkaline phosphatase, Anal. Chim. Acta, 408, 241, 2000.

96. Wilhelm, B. et al., Transglutaminases: Purification and activity assays, J. Chromatogr. B - Biomed. App., 684, 163, 1996.

97. Sakiyama, S.E. et al., Incorporation of heparin-binding peptides into fibrin gels enhances neurite extension: an example of designer matrices in tissue engineering, FASEB J., 13, 2214, 1999. 
98. Sakiyama-Elbert, S.E. et al., Development of growth factor fusion proteins for cell-triggered drug delivery, FASEB J., 15, 1300, 2001.

99. Filmon, R. et al., Poly(2-hydroxy ethyl methacrylate)-alkaline phosphatase: A composite biomaterial allowing in vitro studies of bisphosphonates on the mineralization process, J. Biomater. Sci. Polym. Ed., 11, 849, 2000.

100. Arica, M.Y. et al., Covalent immobilization of alpha-amylase onto pHEMA microspheres: preparation and application to fixed bed reactor, Biomaterials, 16, 761, 1995, chap. 12.

101. Azevedo, H.S. and Reis, R.L., Understanding the enzymatic degradation of biodegradable polymers and strategies to control their degradation rate, in Biodegradable Systems in Medical Functions: Design, Processing, Testing and Applications, Reis, R.L. and Roman, J.S., Eds., CRC Press, Boca Raton, FL, 2004.

102. Fuchsbauer, H.L. et al., Influence of gelatin matrices cross-linked with transglutaminase on the properties of an enclosed bioactive material using beta-galactosidase as model system, Biomaterials, 17, 1481, 1996.

103. Martinez, A.J. et al., Immobilized biomolecules on plasma functionalized cellophane. I. Covalently attached alpha-chymotrypsin, J. Biomater. Sci. Polym. Ed., 11, 415, 2000.

104. Kok, F.N. et al., Immobilization of acetylcholinesterase and choline oxidase in/on pHEMA membrane for biosensor construction, J. Biomater. Sci. Polym. Ed., 12, 1161, 2001.

105. Ganapathy, R. et al., Immobilization of papain on cold-plasma functionalized polyethylene and glass surfaces, J. Biomater. Sci. Polym. Ed., 12, 1027, 2001.

106. Srinivas, S.S. and Rao, K.P., Controlled release of lysozyme from succinylated gelatin microspheres, J. Biomater. Sci. Polym. Ed., 12, 137, 2001.

107. Labeque, R. et al., Enzymatic modification of plasma low density lipoproteins in rabbits: a potential treatment for hypercholesterolemia, Proc. Nat. Acad. Sci. U.S.A., 90, 3476, 1993.

108. Zhu, Y.B. et al., Surface modification of polycaprolactone with poly(methacrylic acid) and gelatin covalent immobilization for promoting its cytocompatibility, Biomaterials, 23, 4889, 2002.

109. Ma, Z.W. et al., Protein immobilization on the surface of poly-L-lactic acid films for improvement of cellular interactions, Eur. Polym. J., 38, 2279, 2002.

110. Ewert, S. et al., Biophysical properties of human antibody variable domains, J. Mol. Biol., 325, 531, 2003.

111. Hern, D.L. and Hubbell, J.A., Incorporation of adhesion peptides into nonadhesive hydrogels useful for tissue resurfacing, J. Biomed. Mater. Res., 39, 266, 1998.

112. Asthagiri, A.R. et al., A rapid and sensitive quantitative kinase activity assay using a convenient 96well format, Anal. Biochem., 269, 342, 1999.

113. Torchilin, V.P. and Trubetskoy, V.S., Which polymers can make nanoparticulate drug carriers longcirculating?, Adv. Drug Del. Rev., 16, 141, 1995.

114. Sherwood, R.F., Advanced drug delivery reviews: Enzyme prodrug therapy, Adv. Drug Del. Rev., 22, 269, 1996.

115. Liang, J.F. et al., ATTEMPTS: a heparin/protamine-based delivery system for enzyme drugs, $J$. Control. Rel., 78, 67, 2002.

116. Bagshawe, K.D. et al., Developments with targeted enzymes in cancer therapy, Curr. Opin. Immunol., 11, 579, 1999.

117. Mori, T. et al., Enzymatic properties of microcapsules containing asparaginase, Biochim. Biophys. Acta, 321, 653, 1973.

118. Chen, J.P. and Chen, Y.C., Preparations of immobilized lysozyme with reversibly soluble polymer for hydrolysis of microbial cells, Bioresour. Technol., 60, 231, 1997.

119. Goth, L., A new type of inherited catalase deficiencies: Its characterization and comparison to the Japanese and Swiss type of acatalasemia, Blood Cells Mol. Dis., 27, 512, 2001.

120. Costa, S.A. et al., Immobilization of catalases from Bacillus SF on alumina for the treatment of textile bleaching effluents, Enzyme Microb. Technol., 28, 815, 2001.

121. Petro, M. et al., Immobilization of trypsin onto "molded" macroporous poly(glycidyl methacrylateco-ethylene dimethacrylate) rods and use of the conjugates as bioreactors and for affinity chromatography, Biotechnol. Bioeng., 49, 355, 1996. 
122. Mullerschulte, D. and Daschek, W., Application of radiation grafted media for lectin affinity separation and urease immobilization - a novel-approach to tumor-therapy and renal-disease diagnosis, Radiat. Phys. Chem., 46, 1043, 1995.

123. Chellapandian, M. and Krishnan, M.R.V., Chitosan-poly (glycidyl methacrylate) copolymer for immobilization of urease, Process Biochem., 33, 595, 1998.

124. Ibim, S.M. et al., Controlled macromolecule release from poly(phosphazene) matrices, J. Control. Rel., 40, 31, 1996.

125. Rejikumar, S. and Devi, S., Preparation and characterization of urease bound on crosslinked poly(vinyl alcohol), J. Mol. Catal. B-Enzym., 4, 61, 1998.

126. Hoffman, A.S. et al., Immobilization of enzymes and antibodies to radiation grafted polymers for therapeutic and diagnostic applications, Radiat. Phys. Chem., 27, 265, 1986.

127. Liu, J.G. and Li, G.X., Application of biosensors for diagnostic analysis and bioprocess monitoring, Sens. Actuat. B-Chem., 65, 26, 2000.

128. Saheki, S. et al., Intestinal type alkaline-phosphatase hyperphosphatasemia associated with livercirrhosis, Clin. Chim. Acta, 210, 63, 1992.

129. Delvaux, M. and Demoustier-Champagne, S., Immobilisation of glucose oxidase within metallic nanotubes arrays for application to enzyme biosensors, Biosens. Bioelectron., 18, 943, 2003.

130. Yang, X.R., Measurements of dissolved-oxygen in batch solution and with flow-injection analysis using an enzyme electrode, Biosensors, 4, 241, 1989.

131. Gould, B.J., Enzymes in clinical analysis: principles updated, in Handbook of Enzyme Biotechnology, 3rd ed., Wiseman, A., Ed., Prentice Hall Ellis Harwood, New York, 1995, p. 311.

132. Qingwen, L. et al., Immobilization of glucose oxidase in sol-gel matrix and its application to fabricate chemiluminescent glucose sensor, Mater. Sci. Eng. C-Biomim. Supramol. Syst., 11, 67, 2000.

133. Zhang, J.K. and Cass, A.E.G., A study of his-tagged alkaline phosphatase immobilization on a nanoporous nickel-titanium dioxide film, Anal. Biochem., 292, 307, 2001.

134. Murai, A. et al., Control of postprandial hyperglycaemia by galactosyl maltobionolactone and its novel anti-amylase effect in mice, Life Sci., 71, 1405, 2002.

135. Posthaus, H. et al., Novel insights into cadherin processing by subtilisin-like convertases, FEBS Lett., 536, 203, 2003.

136. Headon, D.R. and Walsh, G., The industrial-production of enzymes, Biotechnol. Adv., 12, 635, 1994.

137. Hoffman, A.S., Biologically functional materials, in Biomaterials Science: An Introduction to Materials in Medicine, Ratner, B.D., Hoffman, A.S., Schoen, F.J., and Lemons, J.E., Eds., Academic Press, San Diego, 1996, p. 124.

138. Dayan, A.D., Safety evaluation of biological and biotechnology-derived medicines, Toxicology, 105, 59, 1995.

139. Sims, J., Assessment of biotechnology products for therapeutic use, Toxicology Lett., 120, 59, 2001.

140. Hodneland, C.D. et al., Selective immobilization of proteins to self-assembled monolayers presenting active site-directed capture ligands, Proc. Nat. Acad. Sci. U.S.A., 99, 5048, 2002. 
